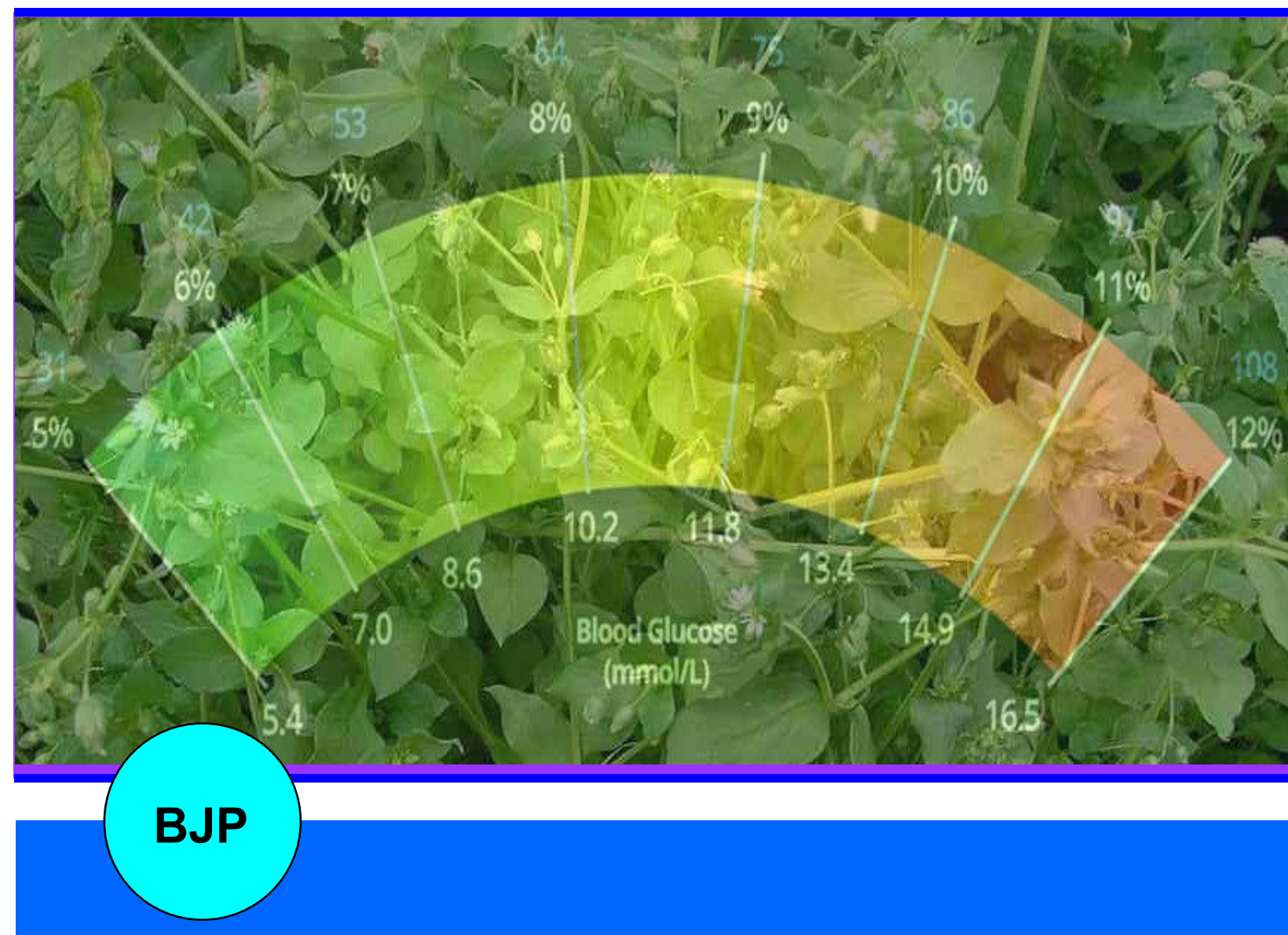

Bangladesh Journal of Pharmacology

Research Article

Stellaria media attenuates the hyperglycemia and hyperlipidemia in alloxan-induced diabetic rat 


\title{
Stellaria media attenuates the hyperglycemia and hyperlipidemia in alloxan-induced diabetic rat
}

\author{
Wasim Ahmad, Mushtaq Ahmad and Rahmat Ali Khan \\ Department of Biotechnology, University of Science and Technology, Bannu-KPK, Pakistan.
}

\begin{tabular}{|c|c|}
\hline \multicolumn{2}{|l|}{ Article Info } \\
\hline Received: & 17 January 2019 \\
\hline Accepted: & 1 April 2019 \\
\hline Available Online: & 28 April 2019 \\
\hline \multicolumn{2}{|c|}{ DOI: 10.3329/bjp.v14i2.39847 } \\
\hline $\begin{array}{l}\text { Cite this article: } \\
\text { Ahmad W, Ahm } \\
\text { Stellaria media att } \\
\text { glycemia and hype } \\
\text { an-induced diabet } \\
\text { Pharmacol. 2019; } 1\end{array}$ & $\begin{array}{l}\text { M, Khan RA. } \\
\text { uates the hyper- } \\
\text { pidemia in allox- } \\
\text { rat. Bangladesh J } \\
\text { 80-86. }\end{array}$ \\
\hline
\end{tabular}

\begin{abstract}
The aim of this research work was to assess the hyperglycemic and hyperlipidemic effects of Stellaria media in alloxan-induced diabetic rat using different experimental models. Standard documented protocols were used to concede the in vitro and in vivo activities. The results showed pancreatic aamylase and $\beta$-glucosidase inhibition in vitro at varying concentrations of the extract which further validated the in vivo anti-diabetic action of the plant. The administration of various concentrations of the extract showed decrease in fasting blood level when compared to diabetic control. Similarly, decreased HbA1c $(-48.4 \%)$ were observed when compared to diabetic control rat. The extract also caused reduced serum transaminase and produced a succeeding recovery toward their normal values. In conclusion, the in vitro and in vivo hypoglycemic and hypolipidemic activity offer the methodical justification for the use of $S$. media in herb based anti-diabetic treatment.
\end{abstract}

\section{Introduction}

Diabetes mellitus is an endocrine abnormalities having numerous etiologies, linking to lipids, protein and carbohydrate metabolic disorders that usually affect the quality of life. Insulin deficiency and insulin resistance are considered to be responsible for all types of diabetes including type 1 and 2 (Narendhirakannan et al., 2006).

The basic aim of all diabetes management strategies is to control and sustain satisfactory blood glucose levels. Oral hypoglycemic drugs and recombinant insulin are being used for the treatment of diabetes. The inhibition of carbohydrate hydrolyzing enzymes is helpful is reducing postprandial blood glucose levels (Tsujita et al., 2008). The two main carbohydrate hydrolyzing enzymes responsible for the breakdown of dietary polysaccharides are a-amylase and a-glucosidase (Daisy et al., 2009). The first step in digestion of dietary starch is catalyzed by the pancreatic a-amylase, which converts the starch into a mixture of small oligosaccharides. After this step, a-glucosidase further degrades the oligosaccharides into glucose. This glucose then diffuses through the intestine wall into the blood stream, increasing postprandial blood glucose levels.

The orally available medicines use is generally associated with the adverse effects together with hematological, cutaneous and gastrointestinal reactions, interrupttion in kidney and liver functioning and hypoglycemic coma (Gandhi et al., 2011). Therefore, it is crucial to continue the quest for newer and effective drugs.

A number of researchers have discovered the antidiabetic potential of flavonoids, cumarins, terpenoids, and other secondary plant metabolites, together with arginine and glutamic acid (Tsujita et al., 2008). Various medicinal plants including Allium cepa (Mathew and Augusti, 1975), Allium satioum (Eidi et al., 2006), Artimisia pallens (Subramoniam et al., 1996), Bidens pilosa (Hsu et al., 2009), Bixa Orellana (Russell et al., 2008), Carum carvi (Haidari et al., 2011), Cassia auriculata (Pari and Latha, 2002), Cassia elata (Palanichamy et al., 1988), Cinnamomum zeylanicum (Verspohl et al., 2005), Coian- 
drum sativum (Gray and Flatt, 1999), Croton cajucara (Farias et al., 1997), Eclipta alba (Ananthi et al., 2003), Embellica officinalis (D'souza et al., 2014), Eruca sativa (Kishore et al., 2017), Gaultheria trichophylla (Alam and Saqib, 2017), Musa sapientum (Pari and Maheswari, 1999) and Teramus labialus (Fort et al., 2000) have shown antidiabetic activity.

Stellaria media belongs to family Caryophyllaceous which is a major dicot family of angiosperms powered by 85 genera and 2630 species (KhareIndian, 2007). S. media or chick weed is known as a noxious weed of the agricultural land. The whole plant is used as an antirheumatic, anti-inflammatory, astringent, refrigerant, demulcent, emollient, vulnerary, antipruritic, infusion used to relieve in itching and to cure psoriasis. The whole plant is applied as a plaster for broken bones and swellings (Shinwari and Khan, 2000). The current work was conceded to study the possible hypoglycemic and hypolipidemic effects of the plant extract in alloxan-

\section{Box 1: $\alpha$-Amylase inhibitory activity}

\section{Principle}

The method is based on quantifying the reducing sugar (maltose equivalent) liberated. The enzyme inhibitory activity is expressed as a decrease in units of maltose liberated. One unit will liberate $1 \mathrm{mg}$ of maltose from starch in $3 \mathrm{~min}$ at $\mathrm{pH} 6.9$ at $20^{\circ} \mathrm{C}$.

$$
\text { Starch + water } \stackrel{\text { a-amylase }}{\longrightarrow} \text { Reducing sugar (maltose) }
$$

\section{Requirements}

Porcine pancreatic a-amylase (Sigma-Aldrich); 3,5-dinitrosalicylic acid; Electronic balance; Stellaria media extract; Micropipette with tips; Mortar and pestle; Potassium sodium tartrate; Sodium phosphate; Starch; Test tube

\section{Preparation of solutions}

Dilution of plant extract: Five different concentrations (100, 200, 300,400 and $500 \mu \mathrm{g} / \mathrm{mL}$ ) of Stellaria media extract as well as acarbose (standard; different concentrations) were prepared

Starch solution (1\%): Weigh $1 \mathrm{~g}$ of starch and dissolve in 100 $\mathrm{mL}$ of buffer solution

a-Amylase solution $(0.5 \mathrm{mg} / \mathrm{mL})$ : Weigh $500 \mathrm{mg}$ of a-amylase and dissolve in $0.2 \mathrm{M}$ sodium phosphate buffer at $\mathrm{pH} 6.9$

3,5-Dinitrosalicylic acid reagent (96 $\mathrm{mM}$ ): Weigh $219 \mathrm{mg}$ in 10 $\mathrm{mL}$ of distilled water by dissolving the powder by heating on a heating/stir plate with mixing. The solution should not heat to boiling point.

Color reagent solution $(40 \mathrm{~mL})$ : Warm $\left(50-70^{\circ} \mathrm{C}\right)$ ultrapure water $(12.0 \mathrm{~mL})$ to a $50 \mathrm{~mL}$ amber bottle. With mixing, slowly add a) warm potassium sodium tartrate, tetrahydrate solution (5.3 M; $8 \mathrm{~mL}$ ) and b) warm 3,5-dinitrosalicylic acid solution (96 $\mathrm{mM} ; 20 \mathrm{~mL}$ )

\section{Procedure}

Step 1: a-Amylase solution $(200 \mu \mathrm{L})$ was mixed with different induced diabetic rats both in vitro and in vivo experiments.

\section{Materials and Methods}

\section{Reagents and chemicals}

The chemicals and standards used in the study were of analytical grade and were obtained from the Sigma. The anti-diabetic drug acarbose (Bayer, Pakistan) was obtained from the local market. HbA1c and hemoglobin tests were executed at the KGN teaching hospital laboratory. The fasting blood glucose sugar was measured by Abbott Glucometer.

\section{Experimental animals}

Male Wister rats having age 8-10 weeks and bearing weight 180-260 $\mathrm{g}$ were obtained from the $\mathrm{NIH}$ Islamabad, Pakistan. The rats were retained in an well-

concentrations of plant extract $(200 \mu \mathrm{L})$. A control test tube was also prepared which was devoid of both plant as well as standard sample

Step 2: The mixed solution was pre-incubated at room temperature for $10 \mathrm{~min}$

Step 3: Following pre-incubation, starch solution $(200 \mu \mathrm{L})$ was added to each tube

Step 4: Incubated for another $3 \mathrm{~min}$

Step 5: The reaction was stopped by the addition of 3,5dinitrosalicylic acid color reagent $(200 \mu \mathrm{L})$

Step 6: The contents were heated in a water bath at $85-90^{\circ} \mathrm{C}$ for $10 \mathrm{~min}$

Step 7: The mixture was allowed to cool to ambient temperature

Step 8: The test tubes were diluted with $5 \mathrm{~mL}$ of distilled water

Step 9: By using UV-Visible spectrophotometer, the absorbance was taken at $540 \mathrm{~nm}$

\section{Calculation}

The \% inhibition of a-amylase was calculated by the following formula:

[(OD control- OD sample)/ OD control $] \times 100$

The same procedure was repeated for standard acarbose as well

\section{Notes}

Color reagent solution is stable for 6 months at ambient temperature if protected from light

\section{Reference}

Miller, 1959 
ventilated room (controlled temperature and 12 hours light-dark cycle) in cages with free access to food and water.

\section{Plant collection and extraction}

The S. media plant was collected locally from the District Bannu-KPK and was identified and authenticated by a taxonomist at the Department of Botany, UST BannuKPK. The leaves of the plant were taken, washed and shade dried. After 25 days, the dried leaves were powered using a blender. $200 \mathrm{~g}$ of powder was macerated in 1L ethanol for 2 weeks following constant shaking and stirring using a shaker machine. After 2 weeks, the extract was filtrated. The filtrate was concentrated using a rotary evaporator until the removal of extraction solvent. The dark green product was subjected to lyophilizer for getting a fine powder which was stored at $4^{\circ} \mathrm{C}$ for future use.

\section{In vitro anti-diabetic assay}

\section{$\beta$-Glucosidase inhibitory activity}

The $\beta$-glucosidase inhibitory activity of the plant extract was determined by using a well-established protocol (Krishnaveni et al., 1984) with some alterations. $290 \mathrm{mM}$ $\beta$-D glucopyranoside ( $\mathrm{pNPGlc}$ ) solution was prepared in $20 \mathrm{mM}$ citrate buffer having a $\mathrm{pH}$ 5.6. Five concentrations of the plant extract and acarbose were prepared. $200 \mu \mathrm{L}$ of plant extract or standard was taken from each concentration and mixed with $980 \mu \mathrm{L}$ of pNPG and incubated at $37^{\circ} \mathrm{C}$ for $5 \mathrm{~min}$. About $20 \mu \mathrm{L}$ of enzyme $\beta$-glucosidase (IU/mL) was added to the above mentioned each mixture and further incubated at $35^{\circ} \mathrm{C}$ for $40 \mathrm{~min}$ in order to stop the reaction, $200 \mu \mathrm{L} 6 \mathrm{~N}-\mathrm{HCl}$ was added to the reaction mixture and the absorbance was taken at $405 \mathrm{~nm}$. The experiment was performed in duplicate. Water was taken as a reference. The \% inhibition was calculated using the equation:

$\%$ Inhibition $=($ Ac-As $) / \mathrm{Ac} \times 100$

Where, Ac is enzyme activity of standard and As is enzyme activity of AgNPs

\section{In vivo anti-diabetic assay}

\section{Diabetes induction in rats}

After an overnight starvation, diabetes was impelled by a single intra-peritoneal injection of alloxan at a dose of $150 \mathrm{mg} / \mathrm{kg}$ body weight. The control animals received normal saline instead of alloxan in an equivalent amount. Since alloxan is capable to cause lethal hypoglycemia because of huge pancreatic insulin release, the animals were provided with $10 \%$ glucose solution just after 6 hours of alloxan administration for the next 24 hours in order to overcome drug-induced hypoglycemia. After 48 hours, the fasting blood glucose was measured to assess the induction of diabetes. The animals with blood glucose level $>200 \mathrm{mg} / \mathrm{dL}$ were considered as diabetic and were further selected for other experimental procedures.

\section{Experimental design}

In the test group, 42 rats were used (30 alloxan-induced diabetic rats; 6 normal control rats and 6 normal extract rats). The groups were arranged as follow: a) Control rats; b) alloxan-induced diabetic rats; c) diabetic rats treated with $S$. media leaf extract $(100,250$ or $400 \mathrm{mg} /$ $\mathrm{kg} /$ day) in saline intraperitoneally for 21 days; d) diabetic rats treated with glibenclamide $(5 \mathrm{mg} / \mathrm{kg} /$ day $)$ in saline intraperitoneally for 21 days; e) normal, nondiabetic rats treated with $S$. media leaf extract $(250 \mathrm{mg} /$ $\mathrm{kg}$ /day) in saline intraperitoneally for 21 days.

The body weight of the rats was measured at day 0 and 21 whereas, the blood glucose level of all rats was measured at fixed interims $(0,3,7,14$ and 21 days). At day 21, the food was with-hold and the rats were starved overnight. Following starvation, the animals were anesthetized and decapitated. The blood was congregated with and without anticoagulant for plasma and serum portion respectively. The liver of animals of various groups (control, diabetic and treated) was preserved for TBARS assay.

\section{Acute toxicity study}

Wister rats were clustered into vehicle-treated 'control' and drug-treated 'test' groups, making up of seven sets of six rats each. The plant extract $(100,150,250,500$, 1000,1500 or $2000 \mathrm{mg} / \mathrm{kg}$ ) was alone injected through intra-peritoneal membrane to the rats in each of the test groups. Every rat in the control group was treated with normal saline only. The animals were studied continuously for 2 hours under the following profiles: a) Behavioral profile including mood alteration, agitation, and irritability; b) neurological profile including touch reaction, pain response, and posture; c) autonomic profile including excretion and urination.

After 24 hours, they were observed for any death or lethality.

\section{Blood biochemistry}

Using a glucometer, blood glucose measurement was taken at different time intervals i.e. 0, 3, 7, 14 and 21 days just after administration of extract on daily basis.

After blood glucose valuation on day 21st, the whole blood was taken by cardiac rupture under slight anesthetic conditions and further glycated hemoglobin and hemoglobin levels were assessed in normal and alloxan induced diabetic rats in laboratory on an automated hematology analyzer (Sysmex, USA).

\section{Isolation of liver}

Soon after collecting blood, the rats were killed by cervical decapitation. The liver was isolated and washed. The liver was sliced and homogenized in 10 $\mathrm{mM}$ Tris- $\mathrm{HCl}$ buffer $(1 / 10, \mathrm{w} / \mathrm{v})$ having $\mathrm{pH} 7.5$. 


\section{TBARS assay}

To assess the lipid peroxidation, TBARS assay was performed according to the protocol published elsewhere (Okhawa et al., 1979; Puntel et al., 2007). The homogenate was centrifuged at $4,000 \times \mathrm{g}$ for $10 \mathrm{~min}$ to yield a pellet that was discarded and the supernatant was used for determining MDA content. $100 \mu \mathrm{L}$ low speed supernatant was incubated for $60 \mathrm{~min}$ at $37^{\circ} \mathrm{C}$ in the presence or absence of extract. After incubation, TBA, $8.1 \%$ SDS and acetate buffer was added and again incubated for $60 \mathrm{~min}$ at $100^{\circ} \mathrm{C}$. The production of light pink color showed the reaction of MDA with TBA. By cooling the tubes using ice, absorbance was measured at $532 \mathrm{~nm}$ using spectrophotometer.

\section{Statistical analysis}

Results were measured as mean \pm SD for 6 rats in an individual group. Statistical evaluation of data was done using SPSS, version 20.0. A p value of $<0.05$ was considered statistically significant.

\section{Results}

\section{a-Amylase inhibitory activity}

In the Table I, the results of a-amylase inhibitory action by the plant extract are mentioned. Ever since, acarbose is considered as reference, its inhibitory activity has been considered as $100 \%$. Based on that, the relative inhibitory activity has been calculated.

\section{$\beta$-glucosidase inhibitory activity}

Table I shows the $\beta$-glucosidase inhibitory action by the plant extract. Ever since, acarbose is considered as reference, its inhibitory activity has been considered as $100 \%$. Based on that, the relative inhibitory activity has been calculated.

\section{Acute toxicity study}

The results of the acute toxicity study showed that the
Table I

Inhibitory activity of $\alpha$-amylase and $\beta$-glucosidase for extract and standard at different concentrations

\begin{tabular}{cccc|}
$\begin{array}{c}\text { Concen- } \\
\text { tration } \\
(\mu \mathrm{g} / \mathrm{mL})\end{array}$ & Acarbose & $\begin{array}{c}\text { a-Amylase } \\
\text { \%inhibition } \\
\text { (extract) }\end{array}$ & $\begin{array}{c}\beta \text {-Glucosidase } \\
\% \text { inhibition } \\
\text { (extract) }\end{array}$ \\
\hline 100 & $68 \pm 0.20$ & $48.1 \pm 0.30$ & $50.1 \pm 0.20$ \\
200 & $72.2 \pm 0.86$ & $55.5 \pm 0.62^{\mathrm{a}}$ & $52.8 \pm 0.42^{\mathrm{b}}$ \\
300 & $77.4 \pm 1.05$ & $60.2 \pm 0.60^{\mathrm{b}}$ & $58.4 \pm 0.40^{\mathrm{a}}$ \\
400 & $80.2 \pm 0.82$ & $72.6 \pm 0.62^{\mathrm{a}}$ & $76.8 \pm 0.52^{\mathrm{b}}$ \\
500 & $88.6 \pm 0.22$ & $74.6 \pm 0.44^{\mathrm{a}}$ & $80.4 \pm 0.44^{\mathrm{b}}$ \\
\hline
\end{tabular}

Values are mean \pm SEM, $n=6$, when compared with diabetic control by using one multiple comparison test, ap $<0.05$; ${ }^{b} \mathrm{p}<0.01$

extract S. media didn't show any modification in the behavior of the test animals. The extract-treated rat did not show any mortality. There was no lethal reaction or toxicity found till $2,000 \mathrm{mg} / \mathrm{kg}$ dosage. This shows the approximate $\mathrm{LD}_{50}$ above $2,000 \mathrm{mg} / \mathrm{kg}$.

\section{Effects of extract on blood glucose levels}

Alloxan-induced diabetic rat showed a remarkable upswing in the blood glucose level when compared to the normal rats. Administration of extract $(400 \mathrm{mg} / \mathrm{kg}$ body weight) caused a momentous decrease in fasting blood level when compared to diabetic control (Table II).

\section{Effects on hemoglobin and HbA1c}

Table II also shows the effect of S. media on hemoglobin and glycosylated hemoglobin levels in normal and alloxan-induced diabetic rats. A significant reduction in hemoglobin $(-30.3 \%)$ and an upsurge in $\mathrm{HbA1c}$ $(+82.5 \%)$ was observed in diabetic animals when compared to normal control group. Administration of S. media remarkably improved hemoglobin $(+20.1 \%)$, and decreased $\mathrm{HbA1c}(-48.4 \%)$ when compared to diabetic control rats.

Table II

Fasting blood glucose, hemoglobin and HbA1c readings of control and test groups

\begin{tabular}{|c|c|c|c|c|c|c|c|}
\hline \multirow[t]{2}{*}{ Groups } & \multicolumn{5}{|c|}{ Fasting blood glucose (mg/dL) } & \multirow{2}{*}{$\begin{array}{l}\text { Hemoglo- } \\
\text { bin (g/dL) }\end{array}$} & \multirow{2}{*}{$\begin{array}{c}\mathrm{HbA1c} \\
(\%)\end{array}$} \\
\hline & Day 0 & Day 3 & Day 7 & Day 14 & Day 21 & & \\
\hline Normal control & $94.2 \pm 4.1^{\mathrm{a}}$ & $96.3 \pm 6.0$ & $97.2 \pm 4.4$ & $88.2 \pm 6.0$ & $87.4 \pm 6.9$ & $13.4 \pm 1.0$ & $4.8 \pm 0.2$ \\
\hline $\begin{array}{l}\text { Normal control + S. media } 250 \\
\mathrm{mg} / \mathrm{kg}\end{array}$ & $92.0 \pm 4.2$ & $92.6 \pm 6.1$ & $88.8 \pm 5.4$ & $87.0 \pm 8.8$ & $84.2 \pm 8.0^{a}$ & $13.0 \pm 1.0^{\mathrm{a}}$ & $5.0 \pm 0.4 \mathrm{~s}$ \\
\hline Diabetic control & $286.8 \pm 8.8^{\mathrm{a}}$ & $308.6 \pm 10^{a}$ & $348.8 \pm 12^{a}$ & $378.8 \pm 15^{\mathrm{a}}$ & $396.6 \pm 12^{a}$ & $9.8 \pm 1.4$ & $8.2 \pm 0.6$ \\
\hline Diabetic + S. media $100 \mathrm{mg} / \mathrm{kg}$ & $286.3 \pm 8.1$ & $274.2 \pm 4.0$ & $250.2 \pm 6.2$ & $230.4 \pm 6.0^{a}$ & $218.0 \pm 6.2^{\mathrm{a}}$ & $12.2 \pm 1.2^{\mathrm{a}}$ & $7.5 \pm 0.2$ \\
\hline Diabetic + S. media $250 \mathrm{mg} / \mathrm{kg}$ & $289.8 \pm 7.2$ & $260.4 \pm 5.0$ & $230.4 \pm 4.0^{a}$ & $171.5 \pm 6.5^{\mathrm{a}}$ & $150.2 \pm 3.0^{a}$ & $11.8 \pm 1.8$ & $6.2 \pm 0.4$ \\
\hline Diabetic + S. media $400 \mathrm{mg} / \mathrm{kg}$ & $288.2 \pm 6.8$ & $264.8 \pm 5.4$ & $222.2 \pm 7.5^{\mathrm{a}}$ & $155.5 \pm 10^{\mathrm{a}}$ & $120.8 \pm 8.2^{\mathrm{a}}$ & $13.0 \pm 1.2^{\mathrm{a}}$ & $5.5 \pm 0.6^{\mathrm{a}}$ \\
\hline $\begin{array}{l}\text { Diabetic + Glibenclamide } 5 \mathrm{mg} / \\
\mathrm{kg}\end{array}$ & $288.4 \pm 6.6$ & $248.1 \pm 8.4$ & $210.4 \pm 8.0$ & $144.4 \pm 8.8$ & $114.28 \pm 7.3^{a}$ & $13.2 \pm 1.4^{\mathrm{a}}$ & $5.4 \pm 0.2^{a}$ \\
\hline
\end{tabular}




\section{Table III}

\section{Effects of extract on liver function tests}

\begin{tabular}{|lccc} 
Groups & ALT (U/L) & ALP (U/L) & Bilirubin (mg/dL) \\
Normal control & $30 \pm 6.40^{\mathrm{a}}$ & $130.8 \pm 1.0$ & $0.70 \pm 6.0$ \\
Normal Control + S. media $250 \mathrm{mg} / \mathrm{kg}$ & $26 \pm 6.40^{\mathrm{a}}$ & $128.4 \pm 1.0^{\mathrm{a}}$ & $0.50 \pm 6.0^{\mathrm{a}}$ \\
& & & \\
& & & $2.18 \pm 6.0$ \\
Diabetic Control & $56 \pm 6.40^{\mathrm{b}}$ & $265.8 \pm 1.0^{\mathrm{b}}$ & $0.9 \pm 6.0^{\mathrm{b}}$ \\
Diabetic + S. media $100 \mathrm{mg} / \mathrm{kg}$ & $42 \pm 6.40$ & $188.2 \pm 1.0^{\mathrm{b}}$ & $0.8 \pm 6.0^{\mathrm{a}}$ \\
Diabetic + S. media $200 \mathrm{mg} / \mathrm{kg}$ & $38 \pm 6.40^{\mathrm{a}}$ & $148.6 \pm 1.0^{\mathrm{a}}$ & $0.8 \pm 6.0^{\mathrm{a}}$ \\
Diabetic + S. media $400 \mathrm{mg} / \mathrm{kg}$ & $26 \pm 6.40^{\mathrm{a}}$ & $130.5 \pm 1.0^{\mathrm{a}}$ & $0.62 \pm 6.0^{\mathrm{b}}$ \\
Diabetic + Glibenclamide $5 \mathrm{mg} / \mathrm{kg}$ & $28 \pm 6.40^{\mathrm{a}}$ & $118.8 \pm 1.0^{\mathrm{a}}$ & \\
\hline
\end{tabular}

\section{Effect of extract on Liver function tests}

Alloxan induced damage in liver cells of the diabetic rats and resulted in an increased serum level of ALT, ALP and bilirubin, in comparison to control group (Table III). The levels were normalized significantly with an administration of extract at a concentration 200 and $400 \mathrm{mg} / \mathrm{kg}$ body weight through oral route. Treatment with glibenclamide $5 \mathrm{mg} / \mathrm{kg}$ body weight following 48 hours of diabetes induction also displayed parallel effect to that of extract $(200 \mathrm{mg} / \mathrm{kg}$ body weight) in diminishing alloxan intoxication in rats.

\section{TBARS assay}

The alloxan-induced diabetes caused an increased level of TBARS both in plasma and liver in comparison to extract treated group (Figure 1).

\section{Discussion}

The results of our study showed high blood glucose level in alloxan induced diabetic rats and its probable reason is the destructive nature of alloxan on $\beta$-cells.
Upon intraperitoneal administration of $S$. media extract $(250,400 \mathrm{mg} / \mathrm{kg})$ and glibenclamide to the diabetic rats markedly decreased blood glucose level. These results were observed from first to fourth week of the study period in comparison to diabetic control rats. Therefore, it might be presumed that anti-hyperglycemic nature of $S$. media is due to its protective nature against alloxan induced $\beta$-cell devastation and imaginable renaissance of impaired $\beta$-cells or an upsurge in insulin secretion or its actions.

Another important clinical marker in diabetes is the glycosylated hemoglobin. It helps to regulate the degree of protein glycation during diabetes mellitus (Aboonabi et al., 2014). In insistent hyperglycemia, formation of HbA1c takes place by non-enzymatic reaction between free amino groups of hemoglobin and glucose. In diabetes mellitus, $\mathrm{HbA1c}$ level are a helping hand to assess long-term glycemic control, and to assess the danger of the progression or development of complications associated with diabetes. In alloxan induced diabetic animals, marked decrease in hemoglobin levels and an increase in $\mathrm{HbA} 1 \mathrm{c}$ levels were noticed in comparison to control group. S. media treatment demonstrated a

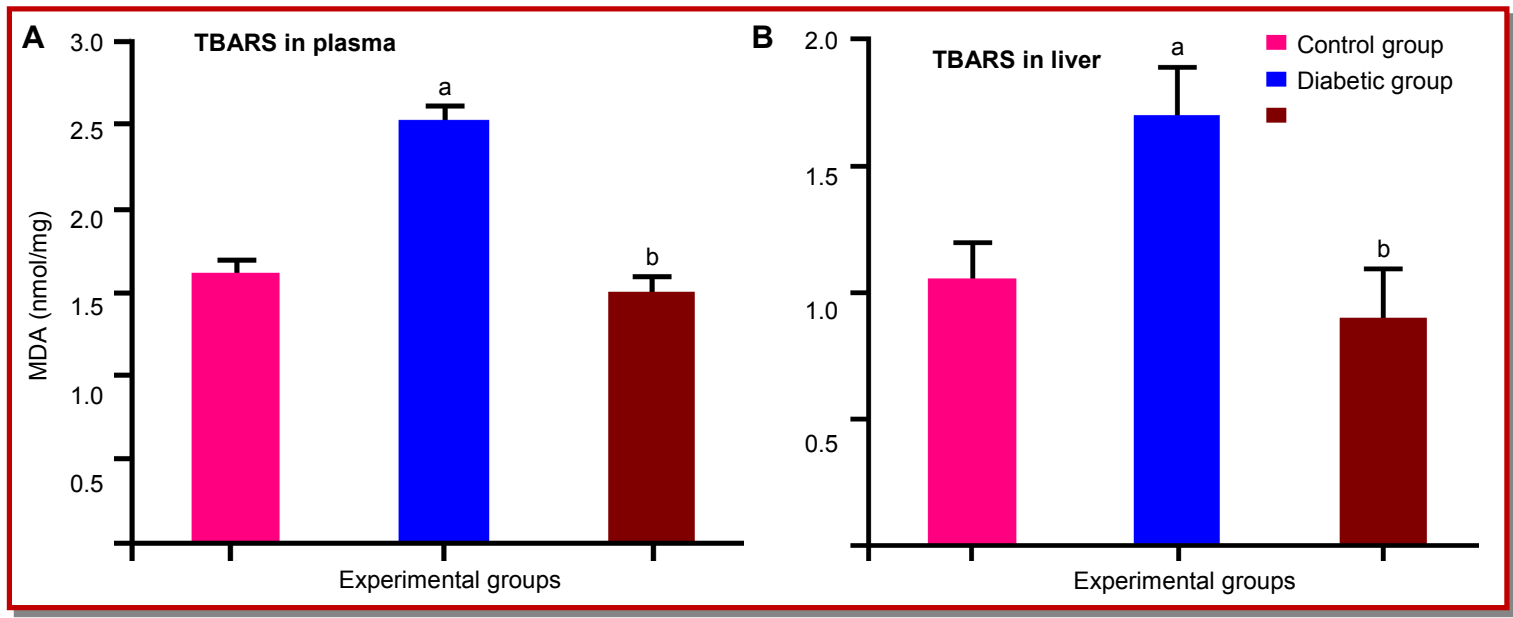

Figure 1: (B) TBARS levels in liver tissues of various experimental groups. a $\mathrm{p}<0.001$ compared to control group; ${ }^{\mathrm{b}} \mathrm{p}<0.001$ compared to diabetic group 
reduction of HbA1c and improvement in hemoglobin levels, and it might be due to blood glucose dropping effects of S. media conceivably through setback of insulin resistance or increasing insulin secretion by rejuvenation of pancreatic $\beta$-cells.

a-Amylase and $\beta$-glucosidase are the two principal enzymes for carbohydrate metabolism present in the small intestine which acts to convert utilized polysaccharides to mono-saccharides. The enzymes action results in an increase in postprandial blood glucose level because of the absorption of synthesized glucose from polysaccharides in the small intestine(Mohammadi and Naik, 2008). Drugs possessing an inhibitory act on both a-amylase and $\beta$-glucosidase, keep a capability to control postprandial blood glucose levels. Acarbose and miglitol are currently available drugs in this category that inhibit above enzymes competitively. But the drugs possess common side effects including abdominal bloating and flatulence (Atmani et al., 2009; Djeridane et al., 2006; Maksimovic et al., 2005; Mburu et al., 2007). The current investigation showed that $S$. media possesses strong pancreatic a-amylase and $\beta$ glucosidase inhibition which further validated the in vivo anti-diabetic action of the plant because of the inhibition of the above enzymes.

Diabetes mellitus is characterized principally by two features, decreased insulin secretion from pancreatic $\beta$ cells and peripheral insulin resistance. Commonly observed sites for insulin resistance are liver, peripheral tissues, skeletal muscle, and adipose tissues. Drug which reduces insulin resistance can efficiently regulate the hyperglycemic state; can normalize lipid metabolism and diabetes-mediated cardiovascular complications (Diouf et al., 2006).

The induction of diabetes with alloxan caused liver damage which is reflected by a momentous upsurge in ALT, ALP, and bilirubin, in comparison with the normal control. The high content of bilirubin is typically a sign of biliary impediment, hemolysis, and renal failure in selected cases (Eidi et al., 2012; Arsad et al., 2014). However, administration of extract reduced serum enzyme levels and produced a succeeding recovery toward normal values. This result indicates an improved hepatoprotective potential of extract.

Lipid peroxidation is a characteristic feature of diabetes as increased lipid peroxidation causes oxidative stress by increasing hydroxyl and peroxy radicals (Motilla et al., 1998). Increased MDA and TBARS levels in diabetic animal's liver and plasma is due to an enhanced lipid peroxidation. The administration of the extract ameliorated the harmful effects of diabetes in treated animal groups.

\section{Conclusion}

S. media in vitro and in vivo hypoglycemic activity provides the methodical justification for its use in herbal anti-diabetic therapy.

\section{Ethical Issue}

The protocol of the study was in accordance with the guidelines of the Brazilian association for laboratory animal science (COBEA).

\section{Conflict of Interest}

There is no conflict of interest.

\section{Acknowledgement}

The authors are extremely thankful to the funding organization, HEC Pakistan, for financial support for the project no 205082/NRPU/RND/HEC 2014.

\section{References}

Aboonabi A, Rahmat A, Othman F. Anti-oxidant effect of pomegranate against streptozotocin-nicotinamide generated oxidative stress induced diabetic rats. Toxicol Rep. 2014; 1: 915-22.

Alam F, Saqib Q. Antidiabetic potential of Gaultheria trichophylla in mice. Bangladesh J Pharmacol. 2017; 12: 29298.

Ananthi J, Prakasam A, Pugalendi KV. Antihyperglycemic activity of Eclipta alba leaf on alloxan-induced diabetic rats. Yale J Biol Med. 2003; 76: 97.

Arsad SS, Esa NM, Hamzah H. Histopathologic changes in liver and kidney tissues from male Sprague Dawley rats treated with Rhaphidophora decursiva (Roxb.) Schott extract. J Cytol Histol. 2014; S4: 001

Atmani D, Chaher N, Berboucha M, Ayouni K, Lounis H, Boudaoud H, Debbache N, Atmani D. Anti-oxidant capacity and phenol content of selected Algerian medicinal plants. Food Chem. 2009; 112: 303-09.

Daisy P, Eliza J, Farook K. A novel dihydroxy gymnemic triacetate isolated from Gymnema sylvestre possessing normoglycemic and hypolipidemic activity on STZ-induced diabetic rats. J Ethnopharmacol. 2009; 126: 339-44.

Diouf PN, Merlin A, Perrin D. Anti-oxidant properties of wood extracts and colour stability of woods. Ann For Sci. 2006; 63: $525-34$.

Djeridane A, Yousfi M, Nadjemi B, Boutassouna D, Stocker P, Vidal N. Anti-oxidant activity of some Algerian medicinal plants extracts containing phenolic compounds. Food Chem. 2006; 97: 654-60.

D'souza JJ, D'souza PP, Fazal F, Kumar A, Bhat HP, Baliga MS. Anti-diabetic effects of the Indian indigenous fruit Emblica officinalis Gaertn: Active constituents and modes of action. Food Funct. 2014; 5: 635-44.

Eidi A, Eidi M, Esmaeili E. Antidiabetic effect of garlic (Allium sativum L.) in normal and streptozotocin-induced diabetic 
rats. Phytomedicine 2006; 13: 624-29.

Eidi A, Mortazavi P, Bazargan M, Zaringhalam J. Hepatoprotective activity of cinnamon ethanolic extract against CCl4-induced liver injury in rats. EXCLI J. 2012; 11: 495-507

Farias RA, Rao VS, Viana GS, Silveira ER, Maciel MA, Pino AC. Hypoglycemic effect of trans-dehydrocrotonin, a norclerodane diterpene from Croton cajucara. Planta Medica. 1997; 63: 558-60.

Fort DM, Rao K, Jolad SD, Luo J, Carlson TJ, King SR. Antihyperglycemic activity of Teramnus labialis (Fabaceae). Phytomedicine 2000; 6: 465-67.

Gandhi GR, Ignacimuthu S, Paulraj MG. Solanum torvum Swartz. fruit containing phenolic compounds shows antidiabetic and anti-oxidant effects in streptozotocin-induced diabetic rats. Food Chem Toxicol. 2011; 49: 2725-33.

Gray AM, Flatt PR. Insulin-releasing and insulin-like activity of the traditional anti-diabetic plant Coriandrum sativum (coriander). Bri J Nutr. 1999; 81: 203-09.

Haidari F, Seyed-Sadjadi N, Taha-Jalali M, Mohammed-Shahi M. The effect of oral administration of Carum carvi on weight, serum glucose, and lipid profile in streptozotocininduced diabetic rats. Saudi Med J. 2011; 32: 695-700.

Hsu YJ, Lee TH, Chang CL, Huang YT, Yang WC. Antihyperglycemic effects and mechanism of Bidens pilosa water extract. J Ethnopharmacol. 2009; 122: 379-83.

KhareIndian CP. Medicinal plants, An illustrated dictionary. Berlin/Heidelberg, Springer-Verlag, 2007, pp 508-83.

Kishore L, Kaur N, Kajal A, Singh R. Extraction, characterization and evaluation of Eruca sativa against streptozotocininduced diabetic nephropathy in rat. Bangladesh J Pharmacol. 2017; 12: 216-27.

Krishnaveni S, Balasubramanian T, Sadasivam S. Sugar distribution in sweet stalk sorghum. Food Chem. 1984; 15: 229-32.

Maksimovic Z, Malencié D, Kovacevié N. Polyphenol contents and anti-oxidant activity of Maydis stigma extracts. Bioresour Technol. 2005; 96: 873-77.

Mathew PT, Augusti KT. Hypoglycaemic effects of onion, Allium cepa Linn. on diabetes mellitus: A preliminary report. Indian J Physiol Pharmacol. 1975; 19: 213-17.

Mburu F, Dumarcay S, Huber F, Petrissans M, Gérardin P. Evaluation of thermally modified Grevillea robusta heartwood as an alternative to shortage of wood resource in Kenya: Characterisation of physicochemical properties and improvement of bio-resistance. Bioresour Technol. 2007; 98: 3478-86.

Miller GL. Use of dinitrosalicylic acid reagent for determination of reducing sugar. Anal Chem. 1959; 31: 426-28.

Mohammadi J, Naik PR. Evaluation of hypoglycemic effect of
Morus alba in an animal model. Indian J Pharmacol. 2008; 40: 15-18.

Motilla P, Vargas JF, Munoz De, Agueda MC, Valdelvira ME, Cabrera ES. Oxidative stress in diabetic rats induced by streptozotocin: Preventive effects of melatonin. J Pineal Res. 1998; 25: 94-100.

Narendhirakannan R, Subramanian S, Kandaswamy M. Biochemical evaluation of antidiabetogenic properties of some commonly used Indian plants on streptozotocininduced diabetes in experimental rats. Clin Exp Pharmacol Physiol. 2006; 33: 1150-57.

Ohkawa H, Ohishi H, Yagi K. Assay for lipid peroxide in animal tissues by thiobarbituric acid reaction. Anal. Biochem. 1979; 95: 351-58.

Palanichamy S, Nagarajan S, Devasagayam M. Effect of Cassia alata leaf extract on hyperglycemic rats. J Ethnopharmacol. 1988; 22: 81-90.

Pari L, Latha M. Effect of Cassia auriculata flowers on blood sugar levels, serum and tissue lipids in streptozotocin diabetic rats. Singapore Med J. 2002; 43: 617-21.

Pari L, Maheswari JU. Hypoglycaemic effect of Musa sapientum L. in alloxan-induced diabetic rats. J Ethnopharmacol. 1999; 68: 321-25.

Puntel RL, Roos DH, Grotto D, Garcia SC, Nogueira CW, Rocha JB. Anti-oxidant properties of Krebs cycle intermediates against malonate prooxidant activity in vitro: A comparative study using the colorimetric method and HPLC analysis to determine malondialdehyde in rat brain homogenates. Life Sci. 2007; 81: 51-62.

Russell KR, Omoruyi FO, Pascoe KO, Morrison EY. Hypoglycaemic activity of Bixa orellana extract in the dog. Methods Find Exp Clin Pharmacol. 2008; 30: 301-05.

Shinwari MI, Khan MA. Folk use of medicinal herbs of Margalla hills national park, Islamabad. J Ethnopharmacol. 2000; 69: 45-56.

Subramoniam A, Pushpangadan P, Rajasekharan S, Evans DA, Latha PG, Valsaraj R. Effects of Artemisia pallens Wall. on blood glucose levels in normal and alloxan-induced diabetic rats. J Ethnopharmacol. 1996; 50: 13-17.

Tsujita T, Takaku T, Suzuki T. Chestnut astringent skin extract, an alpha-amylase inhibitor, retards carbohydrate absorption in rats and humans. J Nutr Sci Vitaminol (Tokyo). 2008; 54: 82-88.

Verspohl EJ, Bauer K, Neddermann E. Antidiabetic effect of Cinnamomum cassia and Cinnamomum zeylanicum in vivo and in vitro. Phytother Res. 2005; 19: 203-06.

You Q, Chen F, Wang X, Luo PG, Jiang Y. Inhibitory effects of muscadine anthocyanins on alpha-glucosidase and pancreatic lipase activities. J Agric Food Chem. 2011; 59: 9506-11.

Author Info

Rahmat Ali Khan and Mushtaq Ahmad (Principal contact)

I e-mail: rahmatgul_81@yahoo.com; mushtaq213@yahoo.com 